\title{
Inhibitory effect of syphilitic rabbit serum on DNA synthesis in rabbit cells in vitro
}

\author{
G H W WONG, B STEINER, R STRUGNELL, S FAINE, AND S GRAVES \\ From the Department of Microbiology, Monash University, Clayton, Victoria, Australia
}

SUMMARY A previously described toxic factor associated with Treponema pallidum (Nichols) and found in extracts of syphilitic rabbit testes has now also been detected in syphilitic rabbit serum. The toxic factor, which inhibits DNA synthesis in baby rabbit genital organ (BRGO) cells in vitro, is present in rabbit serum up to 30 days after infection with $T$ pallidum.

\section{Introduction}

Treponema pallidum (Nichols strain) and extracts of syphilitic rabbit testes inhibit macromolecular (DNA, RNA, and protein) synthesis in rabbit cells in vitro. ${ }^{1}$ This finding was one of very few reports of direct toxicity associated with $T$ pallidum. Fitzgerald $e t a l^{2}$ and Oakes $\mathrm{et}^{\mathrm{al}}{ }^{3}$ have also reported mammalian cell toxicity associated with $T$ pallidum. The relevance of these reports is that tissue destruction in early syphilis may be due to direct treponemal toxicity rather than to the host's inflammatory and immune response to the treponeme as was previously assumed. ${ }^{4}$

We-report a toxic factor that inhibits the synthesis of DNA in rabbit cells in vitro and is detectable in serum from syphilitic rabbits up to $\mathbf{3 0}$ days after infection with $T$ pallidum. Serum from rabbits immunised with heat killed $T$ pallidum was not toxic.

\section{Materials and methods}

\section{RABBIT SERUM SAMPLES}

Three rabbits were injected with viable $T$ pallidum organisms $50 \times 10^{6} /$ testis. The rabbits were bled before infection to provide normal rabbit serum and periodically from five to 150 days thereafter. Control (sham infected) rabbits were injected with heat killed (at $56^{\circ} \mathrm{C}$ for 30 minutes) $T$ pallidum organisms $50 \times 10^{6} /$ testis and bled similarly. Individual samples of serum were stored separately at $-70^{\circ} \mathrm{C}$ until all were ready for experimental use. All serum samples were sterilised by membrane filtration (Millipore $0.45 \mu \mathrm{m}$ ) before coincubation with tissue culture cells.

Address for reprints: Dr S Graves, Department of Microbiology, La Trobe University, Bundoora, Victoria, Australia

Accepted for publication 13 January 1984
PREPARATION OF T PALLIDUM

$T$ pallidum organisms were harvested from infected rabbit testes within two days of the development of orchitis. The testes were cut into small slices that were transferred to a $150 \mathrm{ml}$ bottle containing 30-50 $\mathrm{ml}$ Eagle's minimal essential medium with $10 \mathrm{mmol} / \mathrm{l}$ $\mathrm{N}$-2-hydroxyethylpiperazine- $\mathrm{N}^{1}$-2-ethanesulphonic acid (HEPES) and $20 \%$ fetal calf serum. Reducing agents, which have been shown to be toxic to tissue cells, ${ }^{5}$ were not used in these experiments. The treponemes were extracted from the sliced syphilitic rabbit testes by shaking at $34^{\circ} \mathrm{C}$ for approximately 30 minutes. The $T$ pallidum suspension was centrifuged at $1000 \times g$ for 10 minutes to remove rabbit tissue cells. The supernatant was recentrifuged at $8000 \times g$ for 30 minutes to separate the treponemes, which were then resuspended to the required concentration $\left(10^{8} / \mathrm{ml}\right)$ for injection into rabbit testicles.

\section{ISOLATION AND MAINTENANCE OF TISSUE} CULTURE CELLS

Primary cultures of fibroblastic cells were obtained from one day old New Zealand baby rabbit genital organs (BRGO). The testis tissue was cut, minced, and stirred in phosphate buffered saline (PBS) containing $0.025 \%$ trypsin (Sigma), and $100 \mathrm{U} / \mathrm{ml}$ penicillin and $100 \mathrm{mg} / \mathrm{l}$ streptomycin (Glaxo) at $37^{\circ} \mathrm{C}$ for 30 minutes. The cells were collected, centrifuged at $1000 \times g$ for 10 minutes, and resuspended in Eagle's minimal essential medium supplemented with $20 \%$ fetal calf serum, $10 \mathrm{mmol} / 1 \mathrm{HEPES}$, and antibiotics as above. The cells were then grown in $10 \%$ fetal calf serum without antibiotics at $37^{\circ} \mathrm{C}$, and the medium was changed every three days. The confluent monolayers were subcultured using PBS containing $0.025 \%$ trypsin and $0.001 \%$ ethylenediamine tetraacetic acid (Sigma) to remove cells from the glass. Carbon dioxide and bicarbonate were not used for maintenance of BRGO cells. 
COINCUBATION OF BRGO CELLS WITH

${ }^{3}$ H-THYMIDINE AND SYPHILITIC RABBIT SERUM

About $10^{3}$ BRGO cells were seeded into each well of a 96 well microtitre plate(Sterilin, England) and allowed to attach for 12 hours. This was followed by washing with serum free medium and adding $200 \mu$ l syphilitic rabbit serum (20\% final concentration). Serum from rabbits injected with heat killed $T$ pallidum was added to control wells. After aerobic coincubation for 24 hours, $0.5 \mu \mathrm{Ci}{ }^{3} \mathrm{H}$-thymidine $(20 \mathrm{Ci} / \mathrm{mmol}$, Amersham International, Amersham, England) was added to each well. After incubation for a further 24 hours the BRGO cells were made soluble with $150 \mu \mathrm{l}$ lysis buffer $(0.5 \mathrm{~mol} / 1$ sodium hydroxide and $0.5 \%$ sodium dodecyl sulphate) and washed sequentially with 5\% trichloroacetic acid, water, and methanol. The trichloracetic acid precipitates were collected on to glass fibre filters (Flow Laboratories, Melbourne, Australia) and their radioactivity measured using a Packard Tri-Carb $\beta$ scintillation counter, with 2,5-diphenyloxazole $5 \mathrm{~g} / 1$ and 1,4-bis [2-(3-methyl-5phenyl-oxazolyl)]-benzene $0.4 \mathrm{~g} / 1$ in toluene as the scintilation fluid.

\section{Results}

EFFECT OF SYPHILITIC RABBIT SERUM ON

DNA SYNTHESIS IN BRGO CELLS

Serum from rabbits injected with heat killed $T$ pallidum (50 $\times 10^{6} /$ testis) had no inhibitory effect on DNA synthesis in BRGO cells, while serum taken from rabbits during early syphilis (6 to 30 days after infection) did inhibit DNA synthesis. The figure shows that synthesis was only $40-70 \%$ of that using day 0 rabbit serum from the same rabbits. Serum taken later in the disease (40 to 120 days after infection), however, did not appreciably inhibit the BRGO cells. Heat inactivated and non-inactivated serum samples showed similar results, indicating that the toxic factor in the syphilitic rabbit serum was stable to $56^{\circ} \mathrm{C}$ for 30 minutes (data not shown).

Serum taken from eight other rabbits during peak syphilitic orchitis (11 to 14 days after infection) all inhibited DNA synthesis in BRGO cells by between $64 \%$ and $93 \%$ (mean $81 \%$ ), compared with serum from rabbits injected with heat killed or sonicated $T$ pallidum (data not shown).

\section{Discussion}

At the peak of syphilitic orchitis a soluble factor, which is cytostatic for rabbit cells in culture and apparently of treponemal origin, is present in rabbit testes infected with $T$ pallidum. ${ }^{1}$ This toxic substance may play a part in destruction of local tissue in early syphilis. We have now detected a toxic substance in

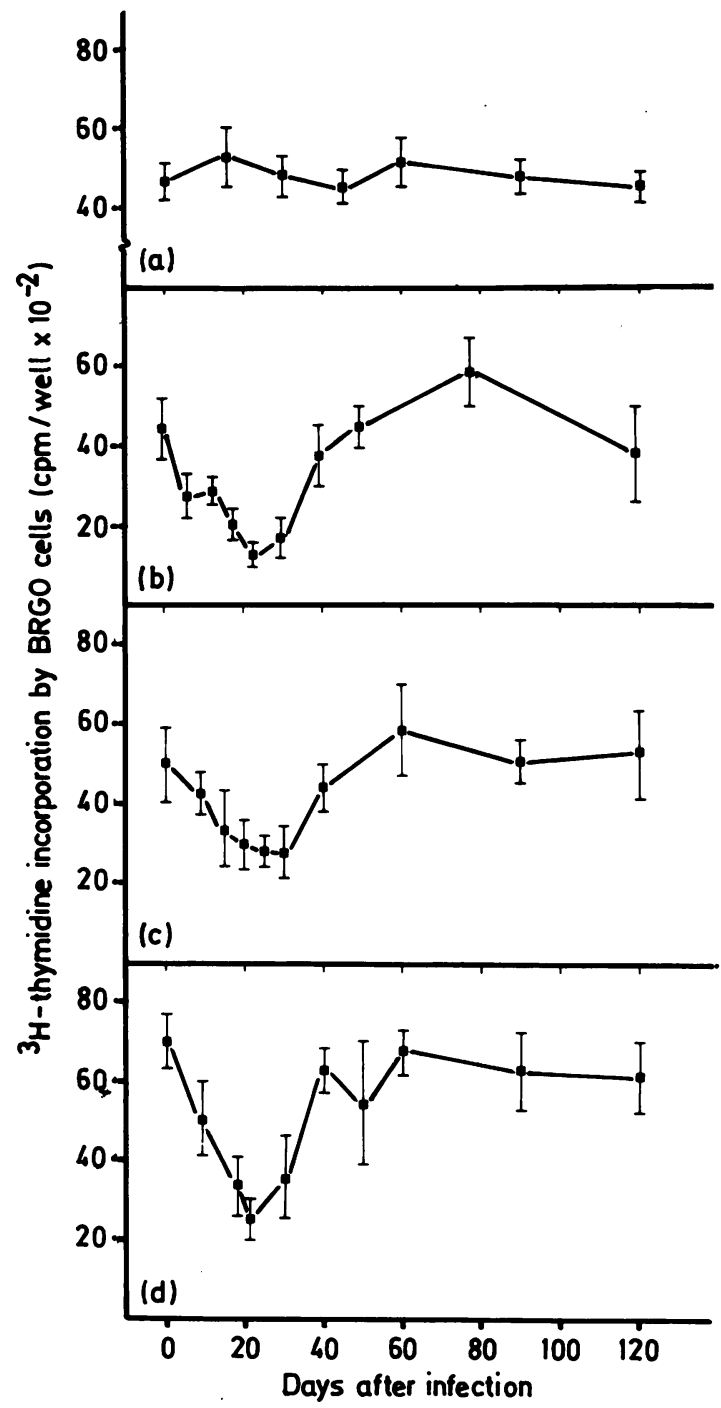

FIGURE Effect of rabbit serum taken at different times after infection with (a) heat killed $T$ pallidum and $(b, c$, and d) viable $T$ pallidum on incorporation of ${ }^{3} \mathrm{H}$-thymidine by BRGO cells. Serum samples were collected periodically from rabbits injected with $T$ pallidum organisms $50 \times 10^{6} /$ testis. Each point is the mean (SD) of five samples.

the serum of syphilitic rabbits up to 30 days after infection. This toxin may reasonably be assumed to be of the same origin as the cytotoxins in whole $T$ pallidum organisms and syphilitic rabbit testes. ${ }^{1}$ It may be responsible for some of the systemic effects of disseminated (secondary) syphilis. The effect of this toxic factor on cells of the host's immune system 
has not yet been tested, but the transient immunosuppression seen in experimental and human syphilis may well be mediated by such a mechanism..$^{6-8}$

Apart from inhibition of DNA synthesis, morphological changes and detachment of BRGO cells were seen after three days' exposure to $10^{8}$ or more treponemes $/ \mathrm{ml} .{ }^{1}$ Uninfected BRGO cells were normal in appearance. The relatively low growth ceiling for $T$ pallidum seen in tissue culture ${ }^{9}$ may be due to inactivation of the mammalian cells by a treponemal toxic factor.

We thank Mrs L Drummond for her excellent technical help. This work was supported by the Australian National Health and Medical Research Council, the Heiser Foundation, the Utah Foundation, and Monash University, from whom funds are gratefully acknowledged.

\section{References}

1. Wong GHW, Steiner BM, Graves S. Inhibition of macromolecular synthesis in cultured rabbit cells by Treponema pallidum (Nichols). Infect Immun 1983;41:636-43.

2. FitzgeraldTJ, Repesh LA, OakesSG. Morphological destruction of cultured cells by the attachment of Treponema pallidum. $\mathrm{Br}$ J Vener Dis 1982;58: 1-11.

3. Oakes SG, Repesh LA, Pozos RS, Fitzgerald TJ. Electrophysiological dysfunction and cellular disruption of sensory neurones during incubation with Treponema pallidum. $\mathrm{Br} J$ Vener Dis 1982;58:220-7.

4. Fitzgerald TJ. Pathogenesis and immunology of Treponema pallidum. Annu Rev Microbiol 1981;35:29-54.

5. Peterkofsky B, Prather W. Cytotoxicity of ascorbate and other reducing agents towards cultured fibroblasts as a result of hydrogen peroxide formation. J Cell Physiol 1977; 90:61-70.

6. Wright DJM, Grimble AS. Why is the infectious stage of syphilis prolonged? Br J Vener Dis 1974; 50:45-9.

7. Pavia CS, Folds JD, Basman JB. Cell-mediated immunity during syphilis. $B r J$ Vener Dis 1978; 54:144-50

8. Bey RF, Johnson RC, Fitzgerald TJ.Suppression of lymphocyte response to concanavalin A by mucopolysaccharide material from Treponema pallidum infected rabbits. Infect Immun 1979; 26:64-9.

9. Fieldsteel AH, Cox DL, Moeckli RA. Cultivation of virulent Treponema pallidum in tissue culture. -Infect Immun 1981; 32: $908-15$. 